\title{
DID HADRIAN EVER MEET A PARTHIAN KING?*
}

\author{
STANISLAV DOLEŽAL
}

\begin{abstract}
There has been an assumption in the scholarly literature about Emperor Hadrian's meeting with a Parthian king in about $123 \mathrm{CE}$. This assumption, based on a single passage in a source whose veracity and reliability has repeatedly been questioned, cannot be proved and appears to be false. However, Hadrian's summit has been accepted without question as a fact in many scholarly books, although some authors chose to ignore this doubtful event. In this article, the whole history of Romano-Parthian relations is briefly summed up and the author tries to point out that, in reality, no summit of heads of these two states ever occurred.
\end{abstract}

Keywords: Parthia; Rome; foreign relations

\section{Introduction}

During his reign, the Emperor Hadrian allegedly met a Parthian king. A single source ${ }^{1}$ tells us that Hadrian held a summit with an Arsacid ruler, presumably on the bank of the Euphrates. Most scholars accept this as a fact, adding just the year (usually $123 \mathrm{CE}$ ), the king's name, and a few speculations about Hadrian's motives. However, it is far more probable that this meeting never took place. In this contribution, I will show that neither during Hadrian's reign nor ever before (and indeed never after) did such meeting between a Roman Emperor and a Parthian monarch occur, and I will also explain why.

"The usual form for encounters between Roman and Parthian heads of state was for them to gather on either bank of the Euphrates, which marked the border between the two realms, and meet face-to-face on an island in the river".2 This quoted passage is typical of superficial knowledge and flawed conceptions of Romano-Parthian relations and foreign politics of both empires. It even implies frequent and regular meetings of heads

\footnotetext{
* This contribution was written in honour of Václav Marek, whose article 'Parthie a Rím v době Augustově' (Parthia and Rome in the Time of Augustus; Marek 2009) it partially reflects and draws upon. All unidentified English translations of sources throughout this article are my own.

1 Hist. Aug., Hadr. 12, 8.

2 Everitt (2010: 122).
} 
of both superpowers, suggesting that such meetings were as politically necessary as they are in the modern world. On the bank of Euphrates or anywhere else, no Roman Emperor ever met any Parthian ruler, at least not in a formal meeting. ${ }^{3}$ As we will see, there were only four meetings in the history of Romano-Parthian relations, in which a ruling Arsacid king took part; none of them, however, included a Roman Emperor. We will see that not only were such summits unnecessary but, on the contrary, they would have been politically dangerous, had they been realized.

\section{The Augustan Peace in the East}

Let us first shortly summarize important events which took place on the border of these two superpowers, with emphasis on diplomatic activity, and then analyse the sources pertaining to the alleged Hadrian's summit. Before the first war between the two empires there were treaties concluded by Sulla, Lucullus, and Pompey. ${ }^{4}$ The very first diplomatic encounter, although we do not know its purpose nor results, set a pattern for all the future Romano-Parthian high-level meetings. In 96 BCE, a Parthian envoy Orobazos, sent by the Parthian king Mithridates II, met Sulla on the Euphates. Plutarch narrates that during negotiations, Sulla slighted the Arsacid king by taking the seat between the Parthian envoy and the king of Cappadocia, Ariobarzanes (the center seat was considered the most honorable). Because of this humiliation, Orobazos was executed upon his return to Parthia. ${ }^{5}$ In all the subsequent negotiations between the two empires, both parties always strove to pose as equals and, if possible, to appear stronger than the opponent.

After Crassus had been killed in the disastrous battle of Carrhae in 53 BCE, the death of Julius Caesar put an end to his preparation for a grand Parthian campaign. ${ }^{6}$ During the subsequent civil war the Parthians sided with his murderers and even launched a fullscale invasion of Roman territories (40 BCE) which was successfully repelled by Mark Antony's general Ventidius Bassus (39-38 BCE). Mark Antony's unfortunate campaign in $36 \mathrm{BCE}$, however, proved to be a lasting obstacle to any further Roman ambitions in the East. ${ }^{7}$

Having crushed Antony and Cleopatra at Actium, Octavianus/Augustus became the undisputed master of the Empire. As Campbell pointed out, he had at this time at least 200.000 soldiers at his disposal. He had enough manpower and resources to undo the damage to the Roman prestige incurred by Crassus and Mark Antony. However, fearing such perilous adventure and not interested in personal glory, he wisely chose not to

3 The closest encounter between rulers of Parthia and Rome seems to have happened in 216 CE, when the Emperor Caracalla feigned that he was willing to marry the daughter of Artabanus IV of Parthia. After he had peacefully entered Parthia and approached the royal palace, he ordered his soldiers to attack the wedding guests and Artabanus barely escaped the massacre. This story is told by Herodian. IV, 10-11, but see Cass. Dio LXXIX, 1 for a slightly different version. The historicity of this episode, however, remains problematic (see Patterson 2013: 193-194).

4 During this period, the Romans generally tried to avoid hostilities with Parthia, while the Parthians were anxious to secure their borders and therefore pursued a peaceful policy towards their western neighbour (Keaveney 1981: 212; 1982: 412).

5 Plut. Sull. 5.

6 Suet. Iul. $44,3$.

7 Marek (2009: 130-131). 
intervene, pursuing rather long-term goals: peace, accommodation over Armenia and establishment of mutual spheres of interest. The means he used to achieve these goals were negotiation, constant threat of direct military intervention and hostages (namely, a son of Phraates IV, whom the Parthian pretender Tiridates brought to Augustus). "In 20 BC Augustus himself travelled to the eastern provinces, but there was no summit with Phraates - diplomacy was not sufficiently advanced for that, and Augustus wished to avoid a public demonstration of equality." 8 Marek rightly points out that any personal negotiation between Augustus and any Parthian king was out of question because sovereignty of both rulers would thus be seriously compromised or wholly negated, regardless of whose soil would be chosen for the conference. ${ }^{9}$ If some kind of a neutral spot were to be chosen, the meeting would indicate mutual equality which, too, was something the Romans were anxious to avoid. There was thus no need for any Roman Emperor to travel to Euphrates in person to settle matters with a Parthian ruler. Instead, a plenipotentiary was always sent, usually a junior member of the ruling house or an experienced general. It should be also noted that all high-level meetings on the Euphrates appear to have taken place at Zeugma, the main crossing of the river, a garrison town and Rome's major stronghold in the East. ${ }^{10}$ We can conclude that in all cases, the exact spot of these meetings was a no-man's land: either the middle of a temporary bridge or an island in the river. However, our sources do not always indicate which of these two options was realized.

And so, in $20 \mathrm{BCE}$, it happened for the first time that representatives of both ruling houses met. The prince Tiberius, then 21-year-old but no beginner in politics, was empowered by Augustus to settle vital matters with Phraates IV. ${ }^{11}$ Without conferring with the king in person, Augustus managed to obtain peace, the Roman standards lost by Crassus at Carrhae, and as many prisoners of war as the Parthians could find. Moreover, Phraates recognized the Roman supremacy in Armenia and the Euphrates as the common boundary between Rome and Parthia. In exchange for all these concessions, Augustus was only asked to abandon Tiridates, return Phraates' son and promise not to

8 Campbell (2002: 222).

9 Marek (2009: 136).

10 Its ruins are today in the vicinity of Birecik, Turkey, and they are partially submerged in the Birecik Dam. See Ball (2002: 165) and Millar (2001: 33).

11 Velleius Paterculus at first omits Tiberius and alludes only to Augustus himself (Vell. II, 92, 2: aberat in ordinandis Asiae Orientisque rebus Caesar, circumferens terrarum orbi praesentia sua pacis suae bona); but he later returns to the story, although he mentions no summit of Tiberius (Vell. II, 94, 4: Nec multo post, missus ab eodem vitrico cum exercitu ad visendas ordinandasque quae sub Oriente sunt provincias, praecipuis omnium virtutum experimentis in eo tractatu editis, cum legionibus ingressus Armeniam, redacta ea in potestatem populi Romani regnum eius Artavasdi dedit. Cuius rex quoque Parthorum tanti nominis fama territus, liberos suos ad Caesarem misit obsides). Suetonius speaks directly of Tiberius (Suet. Tib. 9, 1: dein ducto ad Orientem exercitu regnum Armeniae Tigrani restituit ac pro tribunali diadema imposuit. recepit et signa, quae M. Crasso ademerant Parthi). Levick, who chose to dismiss the testimony of Suetonius, believed that it was Augustus, not Tiberius, who met Phraates IV. Her arguments, however, are both weak and unfounded. Cf. Levick 1999: 13 and especially 190, note 38: "But the silence of Velleius is decisive; and why did Augustus go all the way to Syria only to concede the moment of glory to Tiberius?" We have seen, however, that Velleius is not silent and there certainly was a personal involvement of Tiberius. Why Augustus left all the supposed glory to the junior prince is evident and will be discussed later on. 
make Armenia a Roman province. ${ }^{12}$ As can only be expected, Augustus himself spoke of his undeniable diplomatic success as of triumph: "I compelled the Parthians to restore to me the spoils and standards of three Roman armies and to ask as suppliants for the friendship of the Roman people." 13 In reality, it was a diplomatic solution satisfactory to both parties, but imperial propaganda fed the Roman public with the claim of Roman supremacy. Not only Armenia, but also Parthia was claimed to be a Roman dependency. ${ }^{14}$

However, in 2 BCE, the king Phraates was murdered by his wife Musa who then made her son Phraataces the sole ruler of Parthia. In addition, the Armenian nobility, incited by the Parthians, ousted the Armenian king Artavasdes who had had Roman support. As in $20 \mathrm{BCE}$, neither side wished to go to war and both were in favour of a diplomatic solution. In $1 \mathrm{CE},{ }^{15}$ Augustus' nominated successor and adoptive son, the young prince Gaius, and the Parthian king Phraataces met on the Euphrates. We are eloquently told by an eye-witness, the Roman historian Velleius Paterculus, about all circumstances of the meeting: "On an island in the Euphrates, with an equal retinue on each side, Gaius had a meeting with the king of the Parthians, a young man of distinguished presence. This spectacle of the Roman army arrayed on one side, the Parthian on the other, while these two eminent leaders not only of the empires they represented but also of mankind thus met in conference - truly a notable and a memorable sight - it was my fortunate lot to see early in my career as a soldier, when I held the rank of tribune. I had already entered upon this grade of the service under your father, Marcus Vinicius, and Publius Silius in Thrace and Macedonia; later I visited Achaia and Asia and all the eastern provinces, the outlet of the Black Sea and both its coasts, and it is not without feelings of pleasure that I recall the many events, places, peoples, and cities. As for the meeting, first the Parthian dined with Gaius upon the Roman bank, and later Gaius supped with the king on the soil of the enemy." 16

As for the actual outcome of the meeting, we may assume that compliments were exchanged, but more importantly, the Armenian question was settled. The kingdom was de facto recognized as a Roman dependency. Furthermore, a demarcation line on the Euphrates was settled. It was agreed that the Parthians would withdraw from Armenia and the Romans would not interfere with inner affairs of Parthia. The meeting is not mentioned in Res Gestae Divi Augusti, but why should it be? Augustus knew very well

12 Suet. Aug. 21, 3 (Parthi quoque et Armeniam vindicanti facile cesserunt et signa militaria, quae M. Crasso et M. Antonio ademerant, reposcenti reddiderunt obsidesque insuper optulerunt, denique pluribus quondam de regno concertantibus, non nisi ab ipso electum probaverunt); cf. Cass. Dio LIV, 8.

13 R. gest. div. Aug. 29, 2: Parthos trium exercitum Romanorum spolia et signa reddere mihi supplicesque amicitiam populi Romani petere coegi. Translated by Brunt, Moore (1973).

14 After 20 BCE, there appear proud expressions on Roman aurei and denarii, such as ARMENIA CAPTA (Sutherland 1984: 82), SIGNIS RECEPTIS (Sutherland 1984: 43) or even SIGNIS PARTHICIS RECEPTIS (Sutherland 1984: 83).

15 The event does seem to happen in 1 CE (Edwell 2008: 9; Ball 2002: 15; Campbell 2002: 223; Millar 2001: 33), but Southern (1998: 175) and Romer (1979: 209) opted for 2 CE; Marek (2009: 139) pondered both possibilities.

16 Vell. II, 101: Cum rege Parthorum, iuvene excelsissimo, <in> insula quam amnis Euphrates ambiebat, aequato utriusque partis numero, coiit. Quod spectaculum stantis ex diverso hinc Romani, illinc Parthorum exercitus, cum duo inter se eminentissima imperiorum et hominum coirent capita, perquam clarum et memorabile sub initia stipendiorum meorum tribuno militum mihi visere contigit: quem militiae gradum ante sub patre tuo, M. Vinici, et P. Silio auspicatus in Thracia Macedoniaque, mox Achaia Asiaque et omnibus ad Orientem visis provinciis et ore atque utroque maris Pontici latere, haud iniucunda tot rerum, locorum, gentium, urbium recordatione perfruor. Prior Parthus apud Gaium in nostra ripa, posterior hic apud regem in hostili epulatus est. Translated by Shipley (1924). 
that the treaty had greatly limited any ambitions the Romans may have had in the East. There were no military triumphs over the Parthians to be had in the foreseeable future. The best the Emperor could come up with was this disingenuous statement: "Greater Armenia I might have made a province after its king, Artaxes had been killed, but I preferred, following the model set by our ancestors, to hand over that kingdom to Tigranes, son of King Artavasdes and grandson of King Tigranes; Tiberius Nero, who was then my stepson, carried this out. When the same people later rebelled and went to war, I subdued them through the agency of my son Gaius and handed them over to be ruled by King Ariobarzanes, son of Artabazus King of the Medes, and after his death to his son Artavasdes. When he was killed, I sent Tigranes, a scion of the royal Armenian house, to that kingdom." 17

In $18 \mathrm{CE}$, another Roman prince, Germanicus, almost met another Parthian ruler, Artabanus II, on the Euphrates. According to Tacitus, Germanicus refused, in a modest and courteous manner, the offer of a high-level meeting. ${ }^{18}$ Why? One reason readily presents itself: he knew that Tiberius had recently been very suspicious about his popularity and his motives. Germanicus certainly did not wish to run the risk of being summoned by the Emperor and possibly removed from active political life for good. He had already usurped the imperial prerogatives in Germania, by leading his troops across the Rhine in 14 CE. Seager concludes that Germanicus refused to meet Artabanus "presumably for fear that it might offend Tiberius". ${ }^{19}$ But Germanicus afterwards did offend the Emperor twice: by entering Egypt, a province deemed to be a private estate of the ruling Emperor; and by recalling the provincial governor Piso from Syria to Rome. ${ }^{20}$ There was probably another reason to decline the offer: viewed from the Roman side, the meeting was unnecessary. The Parthian ruler did need it, the Romans did not. In $1 \mathrm{CE}$, everything essential for the future relations was arranged by Gaius under the auspices of Augustus and the Roman authority in the East was restored. In $18 \mathrm{CE}$, there was no need for negotiation, especially when the initiative was taken by the Parthian monarch. We must again emphasize that high-level meetings indicated mutual equality which was precisely what Germanicus and Tiberius needed to avoid. By politely refusing to meet the king, Germanicus wisely kept the upper hand for the Roman side. ${ }^{21}$

That, of course, did not mean that Roman generals were barred from meetings with Parthian monarchs. In 35 CE, Lucius Vitellius, the consul of 34 and father of the future Emperor, was sent to Syria as the new governor for this important province. Probably

17 R. gest. div. Aug. 27, 2: Armeniam maiorem interfecto rege eius Artaxe cum possem facere provinciam malui maiorum nostrorum exemplo regnum id Tigrani regis Artavasdis filio, nepoti autem Tigranis regis, per Ti. Neronem tradere, qui tum mihi privignus erat. Et eandem gentem postea desciscentem et rebellantem domitam per Gaium filium meum regi Ariobarzani regis Medorum Artabazi filio regendam tradidi, et post eius mortem filio eius Artavasdi; quo interfecto Tigranem qui erat ex regio genere Armeniorum oriundus in id regnum misi. Translated by Brunt, Moore (1973). Cf. Tac. Ann. II, 3-4.

18 Tac. Ann. II, 58: ad ea Germanicus ... de adventu regis et cultu sui cum decore ac modestia respondit.

19 Seager (2005: 86).

20 Tac. Ann. II, 59 and 70.

21 Cf. Levick (1999: 115): "Rome was now in a stronger position than she had been eighteen years before. It was her candidate and not the Parthian's who was on the throne of Armenia, and there was no need to acknowledge Parthian equality." 
in $37 \mathrm{CE},{ }^{22}$ he arranged a meeting on an improvised pontoon bridge over the Euphrates with the recently restored Parthian king Artabanus II, who had hitherto lived in exile and who just managed to drive out the Roman-backed pretender Tiridates. The meeting was described by Flavius Josephus: "When Tiberius had heard about these things, he decided to make friends with Artabanus. The king, being asked, gladly complied with this request and met Vitellius at the Euphrates. There was a bridge over the river, and both of them came with their guards, and met in the middle of the bridge. And when they had come to an agreement, Herod the tetrarch erected a rich tent in the middle of the passage, and made a feast for them there." ${ }^{3}$ According to Cassius Dio, Vitellius clearly got the upper hand on the king: "He terrified the Parthian by coming upon him suddenly when he was already close to the Euphrates, and then he compelled him to meet him and sacrifice to the images of Augustus and Gaius, and made a peace with him that was advantageous to the Romans, even securing his sons as hostages." 24 Suetonius adds that Artabanus was forced to pay homage even to the standards of Roman legions. ${ }^{25}$ That was another diplomatic victory for the Romans.

In $49 \mathrm{CE}$, another governor of Syria, Gaius Cassius Longinus, placed a temporary camp at Zeugma to host Meherdates, a pro-Roman claimant to the Parthian throne, as well as Parthian nobles and kings of Osroene and Adiabene. ${ }^{26}$ Discussing possible Roman backing to Meherdates, Cassius acted on the Emperor Claudius' orders who had previously heard the request of Parthian envoys in the senate. The envoys, in the words of Tacitus, summed up the long history of relations between Rome and Parthia in this way: "We have an old friendship with you, begun by agreement at the state level. It is therefore proper that you assist your allies. It is true that we have been rivals but now we defer to you out of respect." ${ }^{27}$ Having heard such deferential speech, Claudius obviously stressed in his reply the Roman supremacy and Parthian obedience. ${ }^{28}$ The previous history of Romano-Parthian relations proved him right: of the two superpowers, Parthia had clearly been the weaker one.

\section{The Neronian settlement}

The conflict with Parthia over Armenia in 58-63 was the next opportunity for both empires to negotiate on the Euphrates. The invasion of Armenia by the Parthians in 52-53 was answered by the new Emperor Nero in 54 by sending Gnaeus Domitius Cor-

22 Levick (1999: 115) places these negotiations "at the very end of Tiberius' principate, so near his death that they could be ascribed to the reign of Gaius" - and they indeed should be. Cf. Seager 2005: 205 ("probably after Tiberius' death") and Millar 2001: 58 ("in AD 37 or 38").

23 Flav. Ioseph. Ant. Iud. XVIII, 101-102; cf. Tac. Ann. VI, 37.

24 Cass. Dio LIX, 27. Translated by Cary (1925).

25 Suet. Vit. 2, 4 (Lucius ex consulatu Syriae praepositus, Artabanum Parthorum regem summis artibus non modo ad conloquium suum, sed etiam ad veneranda legionum signa pellexit.) and Suet. Cal. 14, 3 (accessit ad immensum civium amorem notabilis etiam externorum favor. namque Artabanus Parthorum rex, odium semper contemptumque Tiberi prae se ferens, amicitiam huius ultro petiit venitque ad colloquium legati consularis et transgressus Euphraten aquilas et signa Romana Caesarumque imagines adoravit.).

26 Tac. Ann. XII, 12; Edwell (2008: 16).

27 Tac. Ann. XII, 10: veterem sibi ac publice coeptam nobiscum amicitiam, et subveniendum sociis virium aemulis cedentibusque per reverentiam.

28 Tac. Ann. XII, 11. 
bulo, one of Rome's most experienced generals, to the East. After intensive preparations, Corbulo invaded Armenia in 58 and in two years he had the whole kingdom under control. The Arsacid king Tiridates fled to his brother, the Parthian king Vologaeses. However, the war was not yet over. In 62, Vologaeses managed to defeat the Roman general Paetus in Armenia. In 63, both sides were willing to discuss terms of peace. Corbulo first met Monaeses, an envoy of Vologaeses, on a bridge over the Euphrates. The bridge was deliberately disrupted in the middle, as there was only armistice at the time, not peace. ${ }^{29}$ Then he met Tiridates in Armenia. On the agreed day, both Tiridates and Corbulo, each accompanied by 20 horsemen, met between the two camps. Tiridates removed his diadem and placed it at the feet of Nero's statue. It was agreed that Tiridates would go to Rome where he would receive the diadem again from Nero. ${ }^{30}$ This proposal had already been presented to Nero by Vologaeses' envoys in Rome. By that time, Armenia became "Rome's Afghanistan"31 and although there was much debate about conclusion of the war, Nero finally accepted the Parthian offer. In 66, Tiridates visited Nero in Rome and was crowned king. ${ }^{32}$

By the Neronian settlement, Rome accepted as a possible solution of the Armenian problem the installation of a Parthian nominee, usually a younger son of the ruling Parthian king, on the throne of Armenia, granting its permission and conferring the royal diadem on the person nominated. The kingdom of Armenia thus became a subject of Rome's approval of the chosen Parthian nominee for the throne, although the kingdom of Armenia itself was placed within the Parthian hegemony. The Neronian agreement resulted in an uneasy peace which lasted until Trajan's invasion of Armenia in 114.

At the end of 69, Vespasian was approached by Parthian envoys who offered him 40.000 mounted archers for civil war against Vitellius. ${ }^{33}$ Vespasian thanked Vologaeses, but he refused the help, because the civil war was over. His elder son, Titus, hosted on Euphrates another group of Parthian envoys, probably in $70 .{ }^{34}$ Flavius Josephus provides the full narrative of this event: "Titus did not stay at Antioch but continued his progress immediately to Zeugma, which lies upon the Euphrates. Messengers from the Parthian king Vologaeses came to him there and brought him a crown of gold upon the victory he had gained over the Jews. He accepted it and feasted the messengers, and then came back to Antioch."35

\section{Trajan}

Trajan's Eastern campaign in 114-116 was initiated without any strategic need, let alone a just cause. Parthia was no threat and the mutual treaties were respected. But there was a turbulent political situation at that time in Parthia, which probably struck Trajan as an irresistible opportunity to conquer Parthia once and for all. After Pacorus II (who had

29 Cass. Dio LXII, 22.

30 Tac. Ann. XV, 28-30; Cass. Dio LXII, 23.

31 Ball (2002: 16).

32 Suet. Nero 13.

33 Tac. Hist. IV, 51 speaks of horsemen (aderant legati regis Vologaesi quadraginta milia Parthorum equitum offerentes), Suet. Vesp. 6, 4 mentions archers (promisit ... quadraginta milia sagittariorum).

34 Edwell (2008: 16) places the meeting to $71 \mathrm{CE}$.

35 Flav. Ioseph. Bell. Iud. VII, 5, 2. 
three sons: Axidares, Parthamasiris and Meherdates) reigned his brother (or brother-inlaw) Osroes I (or Chosroes; Khusrau; hwsrw in Parthian) who had to contend for power with Vologaeses III ( $w$ lgšy in Parthian). From the coinage it appears that the former ruled in Babylonia and the latter in Iran. Moreover, there were petty kings - for example Manisares, ruler of Gordyene - and tribal chiefs defying the sovereignty of either great king. ${ }^{36}$

The pretext was, at best, feeble. Cassius Dio narrates that Osroes had deposed the Armenian king Tiridates who had been approved by Rome and put in his place his nephew Axidares; in addition, Axidares received his diadem from the Parthian king, not from the Roman Emperor and the Neronian agreement was thus blatantly breeched. Osroes sent envoys to Trajan to negotiate a settlement. They met Trajan already underway, in Athens, and tried to dissuade him from the aggression. In the meantime, Osroes decided to replace Axidares with another nephew of his, Parthamasiris, and the envoys now suggested that Parthamasiris be recognized and given his diadem by Trajan. ${ }^{37}$ The Emperor dismissed the proposal and continued his journey, arriving at Antioch at the beginning of 114. Having the army assembled, he proceeded to Armenia where he received Parthamasiris in his camp. The king removed his diadem and placed it at the Emperor's feet, waiting to be crowned. Trajan, however, proclaimed the annexation of Armenia as a Roman province. ${ }^{38}$ The king was allowed to leave, but he was murdered shortly afterwards. The Emperor with his huge army - perhaps 80.000 men $^{39}$ - pressed on to Edessa, creating the new province Mesopotamia (and perhaps also Assyria), and spent the winter 115/116 in Antioch. ${ }^{40}$ In 116, he took Ctesiphon without a fight, capturing Osroes' daughter and his golden throne. By that time, the Parthians had resolved their internal differences and incited a widespread revolt. In addition, the Jews in Cyrene, Libya, Cyprus and Egypt revolted, too. ${ }^{41}$ Although Trajan originally planned to annex Parthia as part of the Empire, he ultimately decided instead to place Parthamaspates, son of Osroes, on his father's throne as a Roman client. Following Roman withdrawal from the area, Osroes easily defeated Parthamaspates and reclaimed the Parthian throne. Osroes, however, still had conflicts with his rival Vologaeses III, which must have ended in victory for Vologaeses after 129 since Osroes' coinage ceased to appear in Seleucia in 127/8. Parthia continued to be split.

\section{Hadrian}

On the homeward journey, Trajan fell ill and died. On the news of Trajan's death, Hadrian, then the governor of Syria, proclaimed himself Emperor in Antioch (11 August 117). We are not informed about his immediate decisions regarding the East but it is clear

36 Bennett (2005: 199). Moreover, Bivar (1983: 88) speculated that Pacorus II was still alive and pursuing his claims at that time because of the copper coinage struck in Seleucia and attributed to him.

37 Cass. Dio LXVIII, 17; Bivar (1983: 87).

38 Campbell (2002: 234-235).

39 Bennett (2005: 196).

40 The province Mesopotamia actually covered only the northern parts of Mesopotamia. If ever there was a province called Assyria, it was probably situated beyond the Tigris, in the region called Adiabene (in today Iraqi Kurdistan). Millar (2001: 100-101) remarked that "there is no contemporary evidence for a province called Assyria, and no source earlier than the fourth century claims that there had been one."

41 The so-called Kitos war in 115-117; see Cass. Dio LXVIII, 32, 1-3. 
enough that either he deliberately chose to abandon the Trajan's conquests because of instability elsewhere or that the conquered regions in the East had been lost by the time of Trajan's death and Hadrian could not afford to reconquer them. ${ }^{42}$ In addition, Hadrian made use of exiled Parthamaspates and installed him in Edessa as a puppet Parthian prince in 117; however, the native dynasty was restored in $123 .{ }^{43}$ After a brief stay in Cilicia, Hadrian hastened to Rome, arriving there in July $118 .{ }^{44}$

At this point a word must be said about the sources for the reign of Hadrian. Generally said, they are meagre, written much later and highly problematic. We possess an abridgement of relevant books of Cassius Dio's Historia Romana and a handful of works from the 4th century: Eutropius, Festus, Aurelius Victor, Jerome and Epitome de Caesaribus. Of course there are still later sources, like Orosius, Jordanes or Joannes Malalas, but they are of little help. Additionally, Hadrian is the first Emperor described in a collection of imperial biographies called Historia Augusta but this is more of a curse than of benefit. We should be wary regarding this peculiar source that has been almost universally regarded as extremely unreliable. ${ }^{45}$ Some scholars consider at least the biography of Hadrian to be plausible ${ }^{46}$ but on the whole, this source is so bizarre that it was once rightly compared to a tabloid newspaper. ${ }^{47}$ And it can be easily shown that even Hadrian's biography abounds with errors and misconceptions of many kinds. For example, the anonymous author gives us this strange reason for Hadrian's constant travelling through the Empire: "He was eager to travel so that he may personally learn everything what he had read about various places." 48 But Hadrian did not travel for fun or entertainment. Cassius Dio testifies that the Emperor visited during his reign all provinces and everywhere he went, he "personally viewed and inspected absolutely everything", including soldiers' weapons or living quarters. ${ }^{49}$ Historia Augusta contains a jocose epigram written by Hadrian's contemporary Florus and deemed to be genuine: "I would not want to be an Emperor - to trudge throughout Britain - to hide in (Syria?) - to endure the Scythia's frost." ${ }^{\prime \prime}$ And indeed Dio remarked that "in order that they should be benefited by observing him, he everywhere led a rigorous life and either walked or rode on horseback on all occasions, never once at this period setting foot in either a chariot or a four-wheeled vehicle. He covered his head

42 Ball (2002: 16); Isaac (1990: 25).

43 Ball (2002: 90).

44 Millar (2001: 105).

45 Cameron (2011: 781): "The author of the HA was a frivolous, ignorant person with no agenda worthy of the name at all." Cf. Browning (1982: 727): "The historian must make use of it, but only with extreme circumspection and caution."

46 Boatwright (2002: 21): "Hadrian's biography is agreed to be one of the most veracious in the Historia Augusta."

47 Cameron 1993: 21 ("It is hard to regard it as anything but light reading") and 11 ("often fanciful and trivializing HA, which reads rather like gossip column in a tabloid newspaper, and once read, is hard to forget").

48 Hist. Aug., Hadr. 17, 8 (Peregrinationis ita cupidus, ut omnia, quae legerat de locis orbis terrarum, praesens vellet addiscere).

49 Cass. Dio LXIX, 9, 1-4.

50 Hist. Aug., Hadr. 16, 3 (ego nolo Caesar esse, / ambulare per Britannos, / latitare per ..., / Scythicas pati pruinas). Syriscos is just one of many conjectures suggested for the lacuna in this epigram. Cf. Baldwin (1987). 
neither in hot weather nor in cold, but alike amid German snows and under scorching Egyptian suns he went about with his head bare."51

Hadrian stayed in Italy for about three years (summer 118 - spring 121) and then he embarked on his first provincial tour, which covered the years 121-125.52 At first he visited Gaul, Upper Germany, Raetia and Noricum, then he crossed the English Channel to Britain. After returning to Gaul he came to Spain and spent the winter 122-123 in Tarraco. While there, he received a shocking news: "The Parthian king was threatening to renew the war. Hadrian took immediate steps to deal with the situation: Ti. Claudius Quartinus, who was in Spain as iuridicus, was ordered to collect two of the eastern legions, II Traiana and III Cyrenaica, and take them to the frontier. Hadrian met the king at the Euphrates, and the emergency was over." ${ }^{3}$ When we ponder Hadrian's unparalleled journeys throughout the Empire, we may argue that his personal inspections of frontiers were also without a precedent and that Hadrian perhaps decided to meet the Parthian king in person to settle vital matters more effectively. What if Historia Augusta is right?

As stated above, no high-level meeting at the Euphrates during Hadrian's reign can be proved. Despite this, many scholars have repeated this myth, ${ }^{54}$ starting from the 19 th century, ${ }^{55}$ although it is fair to say that other scholars - including those who thoroughly studied Hadrian's reign and the Romano-Parthian relations - ignore the event altogether. ${ }^{56}$ The myth found its way even into the famous novel Mémoires d'Hadrien by Marguerite Yourcenar.

We can assume that Hadrian left Spain for Antioch in the first half of 123,57 but what do our sources tell us about his whereabouts for the rest of that year? As outlined above, the only source that tells us anything about the meeting is the notoriously unreliable Historia Augusta which deigned to mention this important event in one careless sentence: Bellum Parthorum per idem tempus in motu tantum fuit, idque Hadriani conloquio repressum est. ${ }^{58}$ The standard English translation says: "The war with the Parthians had not at that time advanced beyond the preparatory stage, and Hadrian checked it by a personal conference." 59 But the word colloquium has certainly more meanings than "personal con-

51 Cass. Dio LXIX, 9, 1-4. Translated by Cary (1925).

52 Birley (2008: 136).

53 Birley (2008: 139-140).

54 Morgan 2003: 52 ("He held a summit meeting in the area of Euphrates with the Parthian king Chosroes and seems to have made a peaceful settlement."); Sartre 2005: 146 ("A meeting between Hadrian and the Parthian king on an island in the Euphrates in June 123 demonstrated that peace was assured."); McLynn 2010: 136 ("His summit conference with Chosroes in 123 gave the Parthian king most of what he wanted."); Everitt 2010: 120 ("His aim was to meet the Parthian king, whichever member of the royal family happened to be on the throne for the moment, and dissuade him from aggression.").

55 Rawlinson (1873: 317): “On one occasion alone do we hear of any, even threatened, interruption of the friendly relations subsisting between the two powers; and then the misunderstanding, whatever it may have been, was easily rectified and peace maintained. Hadrian, in A.D. 122, had an interview with Chosroës on his eastern frontier, and by personal explanations and assurances averted, we are told, an impending outbreak."

56 Campbell (2002), Speller (2003), Bivar (1983) and, most significantly, Millar (2001: 105): "Hadrian may have been in Syria in 123, but the period when his visit left the clearest traces in our evidence seems to be from the autumn of 129 to the summer of $130 . "$

57 Birley 2013: 153 ("It is a plausible guess that Hadrian was at the Syrian capital in June 123.").

58 Hist. Aug., Hadr. 12, 8.

59 Magie (1922). 
versation or discussion" (or "peace talks", as the context would indicate). It can denote an impersonal dialogue, a parley or talk in written form, or even a speech addressed to someone. ${ }^{60}$ The expression Hadriani colloquio can, therefore, very well be translated "by Hadrian's diplomacy". ${ }^{1}$

Furthermore, the source does not reveal other important details. We are not given the exact year of the meeting (we must deduce it from the timetable of Hadrian's movements throughout the Empire during his provincial tours), nor the exact spot of the meeting (it could be an island in the Euphrates or the middle of a temporary bridge or someplace else), nor the actual name of the Parthian king. It could either have been Vologaeses or Osroes but the author of Historia Augusta clearly was unaware that there was more than one king in Parthia at any given time during the first decade of Hadrian's reign (as noted above, the struggle for power in Parthia between Osroes and Vologaeses continued at least until 128): "To petty rulers and kings he made offers of friendship, and even to Osdroes, king of the Parthians. To him he also restored his daughter, who had been captured by Trajan, and promised to return the throne captured at the same time. And when some of the kings came to him, he treated them in such a way that those who had refused to come regretted it. He took this course especially on account of Pharasmanes, who had haughtily scorned his invitation." 62 Interestingly, the text now supplies the name of the king, but does not link it with a summit. The context, too, looks now very differently - Hadrian, presumably sitting in Rome, expects his noble guests to come to him, not the other way round. Still later on, we get a surprising picture of Hadrian as liberator of the Parthians: "The Parthians always regarded him as a friend because he took away the king whom Trajan had set over them. The Armenians were permitted to have their own king, whereas under Trajan they had had a governor." ${ }^{3}$ But Hadrian did not depose any Parthian king, quite the opposite: we have seen that he made Parthamaspates a local ruler in Edessa as a puppet Parthian prince in 117 . How can we base a whole story about a summit on single passing remark in a source so unreliable? Perhaps we would be better off not having Historia Augusta at all. ${ }^{64}$

Besides, if we study other sources for Hadrian's reign, we get a completely different picture. Cassius Dio is undoubtedly the most important of historians, not so much for his proximity in time (he wrote his Historia Romana in about 230), but for his full narration.

60 OLD 353. Example: Ov. Pont. II, 4, 1-2: Accipe conloquium gelido Nasonis ab Histro, Attice iudicio non dubitande meo.

61 It is, however, true, that the word colloquium appears twice in the biography of Hadrian and the other instance clearly means "conversation" (Hist. Aug., Hadr. 20, 1).

62 Hist. Aug., Hadr. 13, 8-9: Toparchas et reges ad amicitiam invitavit, invitato etiam Osdroe rege Parthorum remissaque illi filia, quam Traianus ceperat, ac promissa sella, quae itidem capta fuerat. Cumque ad eum quidam reges venissent, ita cum his egit, ut eos paeniteret, qui venire noluerunt, causa speciatim Farasmanis, qui eius invitationem superbe neglexerit. Translated by Magie (1922).

63 Hist. Aug., Hadr. 21, 10-11: Parthos in amicitia semper habuit, quod inde regem retraxit, quem Traianus inposuerat. Armeniis regem habere permisit, cum sub Traiano legatum habuissent. Translated by Magie (1922).

64 If we refute the claim of Historia Augusta that Hadrian personally met a Parthian king, we can still ask why the anonymous author tries to convince us about it at all. Perhaps by inventing a personal meeting between the two rulers, Historia Augusta tries to compare Hadrian and Antoninus Pius who, on the contrary, "induced the king of the Parthians to forego a campaign against the Armenians merely by writing him a letter" (Hist. Aug., Pius 9, 6; translated by Magie 1922) or who refused to return the royal throne to him (ibidem). Certainly, this comparison would be unfavourable to Hadrian but it only leads to another question which we are unable to answer; namely, why would the author of Historia Augusta contrast foreign policies of these Emperors? 
Regrettably, we possess but an abridgment of his narration. Dio first described the Bar Kochba revolt (132-135) and then he went on to briefly mention Parthian affairs: "This, then, was the end of the war with the Jews. A second war was begun by the Alani (they are Massagetae) at the instigation of Pharasmanes. It caused dire injury to the Albanian territory and Media, and then involved Armenia and Cappadocia; after which, as the Alani were not only persuaded by gifts from Vologaesus but also stood in dread of Flavius Arrianus, the governor of Cappadocia, it came to a stop. Envoys were sent from Vologaesus and from the Iazyges; the former made some charges against Pharasmanes and the latter wished to confirm the peace. He introduced them to the senate and was empowered by that body to return appropriate answers; and these he accordingly prepared and read to them." ${ }^{6}$ It is clear that Dio knew only of Vologaeses, not Osroes. Furthermore, Dio fails to mention any other Parthian affair during Hadrian's reign. He stresses Hadrian's peaceful approach in foreign affairs and his preparedness for war: "He lived for the most part at peace with foreign nations; for as they saw his state of preparation and were themselves not only free from aggression but received money besides, they made no uprising." 66

All the remaining sources ignore Hadrian's alleged summit and unanimously claim that Hadrian returned the conquered regions to the Parthians for no good reason. Marcus Cornelius Fronto, a contemporary of Hadrian, is the first who criticizes the Emperor for this: "Instead of holding the provinces which Trajan had conquered and established in various wars, Hadrian chose to abandon them." 67 The historians of the 4 th century are usually very succinct and compendious; we get no narration, just summaries of events. Aurelius Victor only remarked that Hadrian "made peace in the East and returned to Rome"; Epitome de Caesaribus supports this view. ${ }^{68}$ Eutropius devotes to Hadrian's reign little space (some 16 lines in the Monumenta Germaniae Historica edition) and fails to mention any events in the East save the surrendering of the three provinces (Armenia, Mesopotamia and Assyria) to the Parthians which he ascribed to the Hadrian's envy of Trajan's glory. ${ }^{69}$ It goes without saying that no personal meeting with the Parthian ruler is mentioned. Festus tells us the same, even twice. ${ }^{70}$ It is a pity, because as his Breviarium primarily focuses on the East, we would expect more. But it is important to realize that both Eutropius and Festus imply that Hadrian gave up the Eastern territories without any external pressure - he simply chose to do so. Jerome's Chronicle, although listing many detailed events for Hadrian's reign, does not know about any summit or imminent hostilities in 123, and Jordanes' Romana is of no help either as he largely followed Jerome. ${ }^{71}$ Even Joannes Malalas who has otherwise much to say about Syria and Antioch, says nothing at all about Hadrian's diplomacy in the East. ${ }^{72}$

65 Cass. Dio LXIX, 15, 1-2. Translated by Cary (1925).

66 Cass. Dio LXIX, 9, 5. Translated by Cary (1925).

67 Fronto Princ. hist. 2, 8 (Quin provincias manu Traiani captas variis bellis ac novo constituendas omittere maluit quam exercitu retinere).

68 Aur. Vict. Caes. 14, 1: pace ad orientem composita Romam regreditur; cf. Ps.-Aur. Vict. Epit. 14, 10.

69 Eutr. Brev. VIII, 6-7 (Traiani gloriae invidens).

70 Ruf. Fest. Brev. 14, 4 and 20, 3, where he repeats himself.

71 Cf. Hier. Chron. s. a. 117-137 and Iord. Rom. 270. Oros. Hist. VII, 13 not only fails to say anything about Parthia in Hadrian's age, but makes the Emperor a friend of Christians.

72 Ioh. Mal. Chron. 277-280 (Dindorf). 
If we turn to coinage for help, we are even more disappointed: between 121 and 125, there is no hint of Hadrian's eastern journey, a summit or peace, let alone a victory over Parthians. The only allusion to Eastern affairs is EXERCITUS SYRIACUS ${ }^{73}$ which cannot be dated and some scholars even consider "perhaps a complete cessation of coinage" for this period of Hadrian's reign. ${ }^{74}$ In contrast, Trajan's coinage abounds in allusions to Parthia. ${ }^{75}$ There is absolutely no numismatic evidence for Hadrian's personal diplomatic victory on the Euphrates.

Not even archaeology can support any thesis about Hadrian's concern in the East. In the newly acquired Roman Arabia, for example, there were apparently only watchtowers along via Traiana nova and certainly no sophisticated defence-in-depth system. According to Isaac, "the absence of evidence is so striking that an archaeologist has recently wondered whether Hadrian abandoned Arabia."

\section{Conclusion}

In a futile search for causes of the alleged Parthian threat of war and the doubtful Hadrian's summit in 123, Birley ${ }^{77}$ was able to find but two possible reasons:

1. Osroes' daughter and his throne were still in possession of the Romans and the summit, therefore, might have been convoked by Hadrian in order to return them. But if we accept the narrative of Historia Augusta, how are we to explain that Hadrian did return the daughter and only promised to return the throne? Furthermore, we are not informed when the daughter was sent back - it would seem logical that she was allowed to return shortly after 117 and not six years later.

2. Osroes may have objected to Parthamaspates being installed by Hadrian as a ruler in Edessa. But Parthamaspates ruled in Edessa in 118-122 and the news of Parthian menace in the East allegedly came to Hadrian's ears in the beginning of 123, when this problem (provided that it ever was a problem for the Parthians) no longer existed.

No meaningful causes of the summit are supplied by other scholars and it seems that some of them, for example Syme ${ }^{78}$, include the summit in their narratives in a desperate attempt to somehow fill the gap of the years 123 and 124 for which we have little information. Hadrian's summit with a Parthian king, if it had happened, would certainly have had political consequences and it would also have received a backlash from later Roman authors. But there is no trace of it in the extant sources. It is irresponsible to use a single passage in Historia Augusta to make up an event just to complement the itinerary of Hadrian. More to the point, the alleged meeting does not fit into the context of Romano-Parthian relations. Why would Hadrian deliberately forgo the Roman superiority in the mutual relations? The course of events in the East was not always favourable to the Roman side, but

73 Mattingly, Sydenham (1926: 462).

74 Mattingly, Sydenham (1926: 323).

75 For example, PARTHIA CAPTA, REX PARTHUS, REX PARTHIS DATUS (alluding to crowning of Parthamasiris) and of course Trajan's victory title PARTHICUS. Mattingly, Sydenham (1926: 262; 266-267; 269-271; 289-291).

76 Isaac (1990: 122), cf. Bowersock (1983: 104).

77 Birley (2013: 153-154).

78 Syme (1988: 161). 
no Roman Emperor was so desperate that he would feel forced to meet his Parthian counterpart personally. Hadrian was no weak Emperor, and not easily intimidated by a hint of menace. Quite the contrary: he had been an experienced general, a longtime servant of the state and a member of Trajan's personal entourage. At the time of his accession, Rome was at its greatest strength and Parthia was politically split, ravaged by war and economically weakened. Hadrian did abandon Armenia, Mesopotamia and Assyria (if ever there was a province of that name), annulling thus his predecessor's conquests, but throughout his long reign he did his best to secure the imperial borders, never showing a sign of weakness. There was nothing Parthia could realistically expect to gain by war in 123 CE. In fact, after Trajan, the Parthians never constituted a real threat. Even at times when Rome's strength was engaged elsewhere (the Marcomannic wars, the Bar Kochba revolt and the political crises after 192 are the best examples), there was no invasion of Roman territories by the Parthians. ${ }^{79}$ On the contrary, the Roman Emperors after Trajan, given a cause of even a pretext, were all too eager to go to war with Parthia (as the campaigns of Lucius Verus, Septimius Severus or Caracalla amply demonstrate).

Hadrian's meeting with a Parthian king would have no justification, and no precedent as well. We have seen that there were only four high-level meetings on the Euphrates between Parthian kings and high Roman representatives, and only in three of them, Roman crown princes were present: Tiberius in $20 \mathrm{BCE}$, Gaius in $1 \mathrm{CE}$ and Titus in $70 \mathrm{CE}$ (in $37 \mathrm{CE}$, it was general Vitellius who was the father of the future Emperor but not a member of the imperial family). No summit was realized after Hadrian, either. There was never a meeting between the heads of states of Rome and Parthia.

\section{REFERENCES}

Baldwin, B., 1987. 'Where Did the Emperor Lurk? HA, Hadrian 16. 3'. Illinois Classical Studies 12, 181-183. Ball, W., 2002. Rome in the East: The Transformation of an Empire. London / New York: Routledge.

Bennett, J., 2005. Trajan Optimus Princeps. A Life and Times. London / New York: Routledge.

Birley, A. R., 2008. 'Hadrian to the Antonines'. In: A. K. Bowman, P. Garnsey, D. Rathbone (ed.), The Cambridge Ancient History. Volume XI. The High Empire, A.D. 70-192. Second ed. Cambridge: Cambridge University Press, 132-194.

Birley, A. R., 2013. Hadrian: The Restless Emperor. London / New York: Routledge.

Bivar, A. D. H., 1983. 'The Political History of Iran under the Arsacids'. In: E. Yarshater (ed.), The Cambridge History of Iran. Volume 3(1). The Seleucid, Parthian and Sasanian Periods. Cambridge: Cambridge University Press, 21-99.

Boatwright, M. T., 2002. Hadrian and the Cities of the Roman Empire. Princeton: Princeton University Press. Bowersock, G. W., 1983. Roman Arabia. Cambridge, Mass.: Harvard University Press.

Browning, R., 1982. 'Biography'. In: E. J. Kenney (ed.), The Cambridge History of Classical Literature. II. Latin Literature. Cambridge: Cambridge University Press, 723-731.

Brunt, P. A., Moore, J. M. (transl.), 1973. Res Gestae Divi Augusti. The Achievements of the Divine Augustus. With an introduction and commentary by P. A. Moore and J. M. Moore. [Reprinted with corrections 1973.] Oxford: Oxford University Press (reprinted 1983).

Cameron, Al., 2011. The Last Pagans of Rome. Oxford: Oxford University Press.

79 An ill-advised invasion of Syria in 161 by Vologaeses IV is the only exception (see Cass. Dio LXXI, 2) and it was not only repelled by the Romans, but severely punished by capturing Ctesiphon and sacking Seleucia on the Tigris in 165. 
Cameron, Av., 1993. The Later Roman Empire, AD 284-430. Cambridge, Mass.: Harvard University Press.

Campbell, B., 2002. 'War and Diplomacy: Rome and Parthia, 31 BC-AD 235'. In: J. Rich, G. Shipley (ed.), War and Society in the Roman World. London / New York: Routledge, 213-240.

Cary, E. (transl.), 1925. Dio's Roman History. VIII. London: William Heinemann / New York: G. P. Putnam's sons.

Edwell, P. M., 2008. Between Rome and Persia. The Middle Euphrates, Mesopotamia and Palmyra under Roman Control. London / New York: Routledge.

Everitt, A., 2010. Hadrian and the Triumph of Rome. New York: Random House.

Isaac, B., 1990. The Limits of Empire. The Roman Army in the East. Oxford: Clarendon Press.

Keaveney, A., 1981. 'Roman Treaties with Parthia circa 95-circa 64 B.C.'. The American Journal of Philology 102, 195-212.

Keaveney, A., 1982. 'The King and the War-Lords: Romano-Parthian Relations circa 64-53 B.C.'. The American Journal of Philology 103, 412-428.

Levick, B., 1999. Tiberius the Politician. London and New York: Routledge.

Magie, D. (transl.), 1922. The Scriptores Historiae Augustae. I. London: William Heinemann / New York: G. P. Putnam's sons.

Marek, V., 2009. 'Parthie a Rím v době Augustově' [Parthia and Rome in the Time of Augustus]. Acta Fakulty filozofické Západočeské univerzity v Plzni 1/2009, 127-144.

Mattingly, H., Sydenham, E. A., 1926. The Roman Imperial Coinage. Vol. II. Vespasian to Hadrian. London: Spink and son Ltd.

McLynn, F., 2010. Marcus Aurelius: A Life. Boston: Da Capo Press.

Millar, F., 2001. The Roman Near East 31 BC - AD 337. Cambridge, Mass. / London: Harvard University Press.

Morgan, J., 2003. Hadrian: Consolidating the Empire. New York: The Rosen Publishing Group.

OLD = Oxford Latin Dictionary. Oxford: Clarendon Press, 1968.

Patterson, L. E., 2013. 'Caracalla's Armenia'. Syllecta Classica 24, 173-199.

Rawlinson, G., 1873. The Sixth Great Oriental Monarchy or the Geography, History, and Antiquities of Parthia. London: Longmans, Green and Co.

Romer, F. E., 1979. 'Gaius Caesar's Military Diplomacy in the East'. Transactions of the American Philological Association 109, 199-214.

Sartre, M., 2005. The Middle East under Rome. Cambridge, Mass. / London: Harvard University Press.

Seager, R., 2005. Tiberius. Hoboken: Blackwell Publishing.

Shipley, F. W. (transl.), 1924. Velleius Paterculus, Compendium of Roman History. Res Gestae Divi Augusti. London: William Heinemann / Cambridge, Mass.: Harvard University Press (reprinted 1961.)

Southern, P., 1998. Augustus. London / New York: Routledge.

Speller, E., 2003. Following Hadrian. A Second-Century Journey through the Roman Empire. Oxford: Oxford University Press.

Sutherland, C. H. V., 1984. The Roman Imperial Coinage. Volume I. From 31 BC to AD 69. Revised ed. London: Spink and Son Ltd.

Syme, R., 1988. 'Journeys of Hadrian'. Zeitschrift für Papyrologie und Epigraphik 73, 159-170. 